\title{
EIS Investigation of the Corrosion Resistance of Uncoated and Coated Nd-Fe-B Magnets in PBS Solution
}

\author{
Emerson A. Martins, ${ }^{*, a, b}$ Mara C. L. Oliveira, ${ }^{a}$ Jesualdo L. Rossi, ${ }^{a}$ Isolda Costa ${ }^{a}$ and \\ Hercílio G. de Melo ${ }^{*, b}$
}

\author{
${ }^{a}$ Laboratório de Corrosão, Centro de Ciência e Tecnologia de Materiais, Instituto de Pesquisas Energéticas \\ e Nucleares, IPEN/CNEN-SP, Av. Prof. Lineu Prestes, 2242, 05508-000 São Paulo-SP, Brazil \\ ${ }^{b}$ Laboratório de Eletroquímica e Corrosão, Departamento de Engenharia Química, \\ Escola Politécnica da USP, Av. Prof. Luciano Gualberto Trav. 3, No. 380, 05508-900 São Paulo-SP, Brazil
}

\begin{abstract}
O objetivo deste trabalho é investigar o comportamento de corrosão de ímãs $\mathrm{Nd}-\mathrm{Fe}-\mathrm{B}$ produzidos por metalurgia do pó e avaliar a proteção conferida por dois diferentes tratamentos de superfície: uma camada de conversão de fosfato e um silano não-funcional. Os ensaios eletroquímicos foram realizados em solução tampão de fosfato (PBS) com $\mathrm{pH}$ neutro, em que a concentração iônica coincide com a do corpo humano. A corrosão foi monitorada por meio de espectroscopia de impedância eletroquímica (EIS), curvas de polarização anódica, e as análises de MEV-EDS foram utilizadas para observar a superfície e controlar a deposição do revestimento. A resposta de EIS evidenciou um comportamento de eletrodo poroso para os ímãs Nd-Fe-B de acordo com a teoria de Levie. Os resultados também indicaram um bom desempenho da camada de fosfato, enquanto o silano não funcional não melhorou a resistência à corrosão dos ímãs. O bom desempenho anti-corrosão da camada de fosfato foi explicada com base na formação de uma camada de fosfato insolúvel tanto na superfície do eletrodo quanto nas paredes dos poros. A precipitação de fosfato de $\mathrm{Nd}$ insolúvel sobre a fase rica em $\mathrm{Nd}$ também contribui para a proteção contra a corrosão oferecida por este revestimento.
\end{abstract}

The aim of this work is to investigate the corrosion behavior of powder metallurgy produced $\mathrm{Nd}-\mathrm{Fe}-\mathrm{B}$ magnets and to evaluate the corrosion protection afforded by two different surface treatments: a phosphate conversion and a non-functional silane (BTSE) layer. The electrochemical tests were performed in a phosphate buffered solution (PBS) at neutral $\mathrm{pH}$, which ionic concentration coincides with that of the human body. The corrosion behavior was monitored by means of electrochemical impedance spectroscopy (EIS) and anodic potentiodynamic polarization curves, and SEM-EDS analyses were used to monitor coating deposition. EIS response has evidenced a porous electrode behavior for the $\mathrm{Nd}-\mathrm{Fe}-\mathrm{B}$ magnets according to the de Levie theory. The results also indicated a good performance of the phosphate layer, whereas the BTSE layer did not improve the corrosion resistance of the magnets. The good anticorrosion performance of the phosphate layer was explained on the basis of the formation of an insoluble phosphate layer both on the electrode surface (identified by interference colors) and on the pore walls. Precipitation of insoluble Nd phosphate on the Nd-rich phase also contributes to the superior corrosion protection afforded by this coating.

Keywords: corrosion, Nd-Fe-B magnets, EIS, dentistry, porous electrode behaviour

\section{Introduction}

Since $\mathrm{Nd}_{2}-\mathrm{Fe}_{14}-\mathrm{B}$-based rare earth magnets were first reported in the $1980 \mathrm{~s},{ }^{1}$ they have been applied in various different fields owing to their excellent magnetic properties such as high magnetization and high coercivity. These magnets have found applications in automobiles, personal

*e-mail: emerson.martins@usp.br,hgdemelo@usp.br computers, consumer electronics, acoustics, biomedical uses, etc. ${ }^{2}$

Magnets have been used in dentistry for many years, most commonly to aid retention of oral and maxillofacial prosthesis. In orthodontics, they are used both for research purposes and in clinical practice, particularly in the treatment of unerupted teeth, in the tooth movement, expansion, fixed retention, and more recently in the correction of an anterior open bite. In the last years these 
Table 1. Chemical composition (wt.\%) of the Nd-Fe-B used in the present study

\begin{tabular}{ccccccccccccc}
\hline $\mathrm{Fe}$ & $\mathrm{Nd}$ & $\mathrm{B}$ & $\mathrm{Dy}$ & $\mathrm{Al}$ & $\mathrm{Co}$ & $\mathrm{Si}$ & $\mathrm{Cu}$ & $\mathrm{Nb}$ & $\mathrm{Na}$ & $\mathrm{Ca}$ & $\mathrm{S}$ \\
\hline 50.59 & 28.31 & 1.0 & 2.09 & 3.73 & 1.28 & 1.39 & 0.18 & 0.66 & 0.41 & 0.15 & 0.16 \\
\hline
\end{tabular}

magnets have shown spectacular improvements in the maximum energy product, and this has led to important reductions in the size required to produce a particular magnetic flux. ${ }^{3}$

However, at the same time, $\mathrm{Nd}-\mathrm{Fe}-\mathrm{B}$ magnets produced by powder metallurgy are notorious for their poor corrosion resistance due to their intrinsic porosity and complex microstructure. Corrosion causes surface degradation and deteriorates their magnetic properties. According to literature ${ }^{4}$ the main reason for the low corrosion resistance of these magnets is the fast oxidation of the Nd-rich $\left(\mathrm{Nd}_{4} \mathrm{Fe}, \eta\right.$-phase $)$ and $\mathrm{B}$-rich $\left(\mathrm{NdFe}_{4} \mathrm{~B}_{4}, \eta\right.$-phase $)$ phases located at the grain boundaries of the magnetic $\Phi$-phase (tetragonal compound $\mathrm{Nd}_{2} \mathrm{Fe}_{14} \mathrm{~B}$ ). Numerous attempts have been conducted to improve the corrosion behavior of $\mathrm{Nd}-\mathrm{Fe}-\mathrm{B}$ magnets, such as alloying elements additions, ${ }^{5}$ and surface coatings by either metals ${ }^{6}$ (commonly Ni or $\mathrm{Zn}$ ) or polymeric resins. ${ }^{7}$

Treatments based on the use of organo-silane coupling agents are attractive for their environmental compliance and good corrosion and adhesion properties. Thin protective silane films are normally obtained by the interaction between hydrolyzed silane solutions and metal substrates by forming strong covalent bonds $\mathrm{Si}-\mathrm{O}-\mathrm{Me}$ (Me stands for metals). In the last years silanization has been investigated as protective method for iron, ${ }^{7}$ aluminum alloys, ${ }^{8}$ zinc or electro-galvanized steels, ${ }^{9}$ magnesium, ${ }^{10}$ and copper. ${ }^{11}$ Hu et al. ${ }^{12}$ reported only a poor increase in the corrosion resistance of silane coated $\mathrm{Nd}-\mathrm{Fe}-\mathrm{B}$ magnets in $\mathrm{NaCl}$ solution, which was ascribed to preferential adsorption of the silane film on the Fe-rich phase and also to the porous nature of the material.

Phosphating is a surface treatment often used as pretreatment prior to coatings application. Only recently, phosphating of $\mathrm{Nd}-\mathrm{Fe}-\mathrm{B}$ magnets and its effect on their corrosion resistance have been studied. ${ }^{13,14}$ However, the results of these studies have shown that improved protection could be obtained only when slightly higher $\mathrm{pH}$ (3.8) was employed in relation to traditional phosphating baths (1.5 to 3.0). This is mainly due to the high susceptibility to corrosion of these types of materials. Phosphating baths of low $\mathrm{pH}$ were found too aggressive towards the tested magnets.

The purpose of the present work is to investigate the corrosion resistance of powder metallurgy produced $\mathrm{Nd}-\mathrm{Fe}-\mathrm{B}$ magnets in phosphate buffered solution (PBS), and to evaluate the anticorrosion properties of two different surface treatments by electrochemical techniques. The electrochemical investigation was carried out through electrochemical impedance spectroscopy (EIS) and anodic and cathodic polarization curves. Scanning electron microscopy (SEM) and energy dispersive X-ray analysis (EDS) were employed to assess the microstructure and the composition of the coatings, respectively.

\section{Experimental}

The material used in this study was a $\mathrm{Nd}-\mathrm{Fe}-\mathrm{B}$ commercial magnet supplied by CRUCIBLE Co. (known as Crumax). This magnet is prepared by powder metallurgy, and its chemical composition is given in Table 1. The chemical elements $\mathrm{Dy}, \mathrm{Al}, \mathrm{Nb}, \mathrm{Co}, \mathrm{Si}$ and $\mathrm{Cu}$ are added to increase and improve the magnetic and corrosion properties and $\mathrm{Na}, \mathrm{Ca}$ and $\mathrm{S}$ are probably impurities.

For electrochemical evaluation disc specimens of $12 \mathrm{~mm}$ diameter and $4 \mathrm{~mm}$ thickness were embedded with cold resin setter, after all the electrical contacts had been adequately established, leaving only one face exposed to the electrolyte. The specimens were then ground up to 1200 grit emery paper and cleaned with distilled water and alcohol prior to the corrosion tests.

All the corrosion studies were carried out at room temperature $(25 \pm 2)^{\circ} \mathrm{C}$ in naturally aerated and unstirred aqueous PBS, whose composition is shown in Table 2. All the solutions were prepared with deionized water using commercially available P.A. reagents.

Table 2. Composition of the PBS solution

\begin{tabular}{ccc}
\hline $\mathrm{NaCl} /\left(\mathrm{g} \mathrm{L}^{-1}\right)$ & $\mathrm{Na}_{2} \mathrm{HPO}_{4} /\left(\mathrm{g} \mathrm{L}^{-1}\right)$ & $\mathrm{KH}_{2} \mathrm{PO}_{4} /\left(\mathrm{g} \mathrm{L}^{-1}\right)$ \\
\hline 8.77 & 1.42 & 2.72 \\
\hline
\end{tabular}

The BTSE (bis-1,2-triethoxysilylethane) solution was prepared by adding $4 \%(\mathrm{~m} / \mathrm{m})$ of BTSE molecules to a 1:1 $(\mathrm{m} / \mathrm{m})$ ethanol/water solution, which, afterwards, had its $\mathrm{pH}$ adjusted to a value between $3.5-4.0$ by the addition of acetic acid. The solution was then left to hydrolyze for 30 min under constant stirring. For coating deposition the magnets were immersed in the hydrolyzed solution during $2 \mathrm{~min}$. Curing was performed in an oven during $30 \mathrm{~min}$ at a temperature of $\left(100 \pm 2{ }^{\circ} \mathrm{C}\right)$.

The phosphate conversion coating is based in a solution of $10 \mathrm{~g} \mathrm{~L}^{-1} \mathrm{NaH}_{2} \mathrm{PO}_{4}$, acidified with $\mathrm{H}_{3} \mathrm{PO}_{4}$ to $\mathrm{pH}$ 3.8. The 
coating was obtained by immersion of the magnets in the phosphating bath, at room temperature during periods up to $24 \mathrm{~h}$.

All the electrochemical tests were performed using a classical three electrodes cell arrangement with $\mathrm{Ag} / \mathrm{AgCl}$ (saturated $\mathrm{KCl}$ ) and a platinum grid as reference and counter electrode, respectively. For the electrochemical impedance spectroscopy (EIS) experiments a Solartron ${ }^{\circledR} 1260$ frequency response analyzer coupled to a Solartron ${ }^{\circledR} 1287$ electrochemical interface was used. The measurements were performed at the open circuit potential (OCP) in the $10 \mathrm{kHz}$ to $10 \mathrm{mHz}$ frequency range. The acquisition rate was 8 points per decade and the ac signal amplitude $15 \mathrm{mV}$ (rms). Open circuit potential (OCP) was recorded prior and after the completion of each experiment in order to verify that stationarity requirements were obeyed, and the overall results showed a variation of about $\pm 15 \mathrm{mV}$ around the initial OCP. At least triplicate measurements were performed for each condition and the results were reproducible within the expected range, allowing differentiating between the corrosion behaviors of each surface condition.

Anodic potentiodynamic polarization curves were obtained at independent experiments at $1.0 \mathrm{mV} \mathrm{s}^{-1}$ using the same electrochemical interface employed in the EIS experiments. The curves were initiated after OCP stabilization during $30 \mathrm{~min}$.

The equipment used to perform the SEM/EDS analyses was a Philips XL-30 scanning microscope equipped with an EDS spectrometer. The acceleration voltage used to perform the EDS analyses was $20 \mathrm{keV}$, giving a penetration depth of approximately $1 \mu \mathrm{m}$. Semi-quantitative elemental analyses were performed using internal standards of the equipment.

\section{Results and Discussion}

Figure 1 presents the anodic polarization curves for the polished Nd-Fe-B magnet and for samples protected with the two different coatings (silane or phosphate produced by $24 \mathrm{~h}$ immersion) after $1 \mathrm{~h}$ immersion in the PBS test solution. The curve for the sample protected with the BTSE layer presents a net depolarization when compared with the polished magnet, indicating that this coating is inefficient. On the other hand, a more polarized curve was obtained for the phosphated sample, indicating that this treatment improves the anticorrosion properties of the magnet.

EIS diagrams for a polished magnet after different immersion times in the PBS solution are shown in Figure 2; there is no relevant change during this period indicating that the system has attained its steady state. Two relaxation

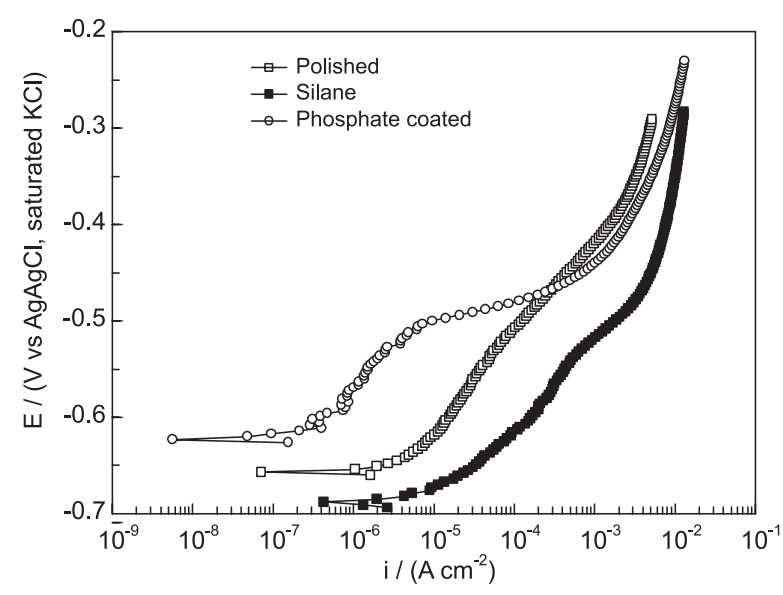

Figure 1. Potentiodynamic anodic polarization curves for polished uncoated $\mathrm{Nd}-\mathrm{Fe}-\mathrm{B}$ magnet and for samples protected by phosphate conversion coating and silane (BTSE) layer. Curves obtained after $1 \mathrm{~h}$ immersion at $1.0 \mathrm{mV} \mathrm{s}^{-1}$. The phosphate-coated sample was treated during $24 \mathrm{~h}$ in the phosphating solution.

phenomena are easily distinguished in the diagrams: at high frequencies a depressed loop is characterized, while at low frequencies a straight line indicates the existence of diffusion controlled processes.

Figure 2c presents the Nyquist diagram acquired after $1 \mathrm{~h}$ of immersion in the PBS solution. In this Figure is possible to verify that the high frequency capacitive loop makes a $45^{\circ}$ angle with the real axis. Normally this kind of response is associated to diffusion controlled processes (Warburg impedance), however, due to the extremely high frequency where this loop occurs this response cannot be ascribed to such phenomenon, as solution diffusion of chemical species, either ions or molecules, is not an extremely fast process. During the sixties de Levie showed that the EIS response of a porous electrode is characterized by a Warburg-like behavior. ${ }^{15-17}$ Using a series of simplifying hypothesis ${ }^{16}$ the author demonstrated that the impedance of a porous electrode can be calculated as follows: ${ }^{18}$

$\mathrm{Z}_{\text {de Levie }}=\left(\mathrm{R}_{0} \mathrm{Z}_{0}\right)^{1 / 2} \operatorname{coth}\left(l \sqrt{\frac{\mathrm{R}_{0}}{\mathrm{Z}_{0}}}\right)$

Where $\mathrm{R}_{0}$ is the electrolyte resistance for a one-unit length pore in $\Omega \mathrm{cm}^{-1}, \mathrm{Z}_{0}$ is the interfacial impedance for a one-unit length pore in $\Omega \mathrm{cm}$ and $l$ is the length of each pore in $\mathrm{cm}$. When 1 is large enough, which means that the pores behave as if they were semi-infinitely long, the coth term of the equation tends to 1 , and the phase angle tends to $45^{\circ}$ independently of the frequency, like in the Warburg impedance. Taking into account the de Levie theory and the porous nature of the working electrode, which is produced by powder metallurgy, the high frequency time constant would be ascribed to the response of the porous 
(a)

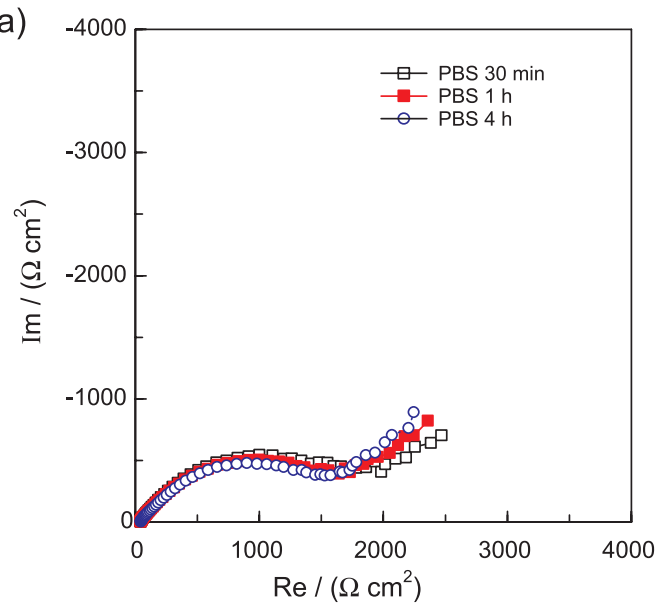

(b)

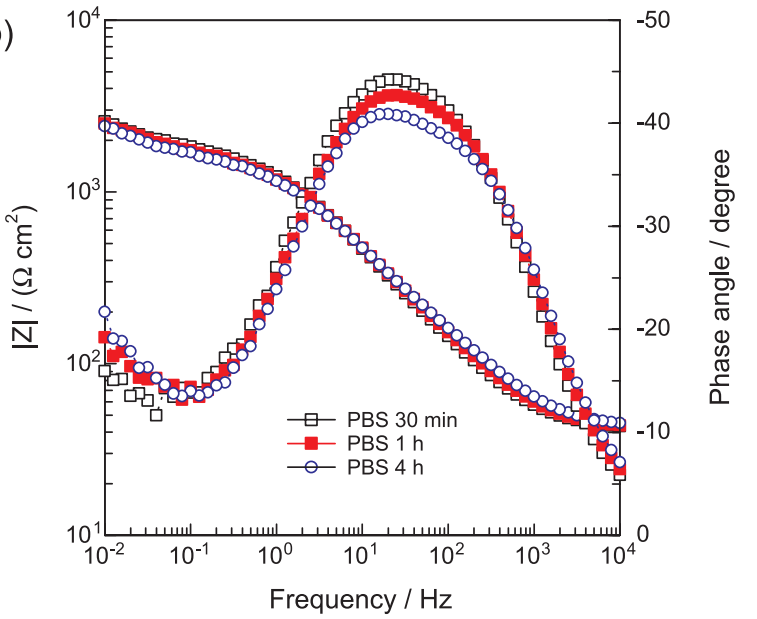

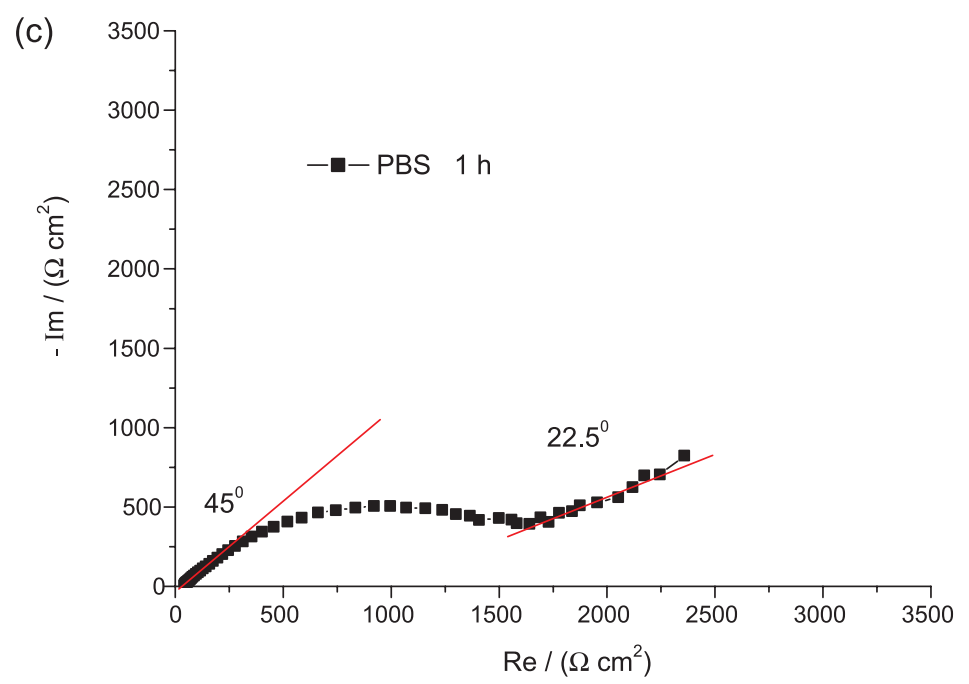

Figure 2. Nyquist (a) and Bode (b) diagrams for a Nd-Fe-B magnet after different immersion times in PBS solution; (c) Nyquist diagram obtained after $1 \mathrm{~h}$ immersion showing the angles with the real axis.

system. In this situation the electrochemical reactions take place at the conductive pore walls, which surface area is superior to that of the flat surface area, and phase angles are divided by two when compared with the typical response of flat electrodes.

Regarding the second time constant, the diagram depicted in Figure 2c shows that the angle of the straight line with the real axis is around $22.5^{\circ}$. De Levie also showed that the angle with the real axis of aWarburg impedance (diffusion controlled process) in a porous electrode with semi-infinite pore length is half that presented by a flat electrode. ${ }^{16}$ Therefore, the low frequency time constant indicates that diffusion within the pores controls the low frequency impedance behavior. Taking into account these experimental results it is possible to say that the EIS response of the electrode in the whole frequency range is governed by a porous electrode behavior, in accordance with its production procedures: by powder metallurgy.
Figure 3 depicts the EIS diagrams, after $1 \mathrm{~h}$ immersion in the PBS solution, for a polished magnet and for samples protected with the phosphate coating and with the BTSE layer. In accordance with the results presented in Figure 1, the phosphate-coated sample presented a better EIS response than the polished magnet, while the EIS behavior of the BTSE-coated sample was the worst. Moreover, the impedance exhibited by the sample treated in the phosphating bath was more than one order of magnitude higher than that exhibited by the polished sample pointing towards very effective protective properties.

The Bode plots, Figure 3b, for the phosphate and BTSE-coated samples, are clearly composed of at least two time constants. As the highest frequency one is displaced to higher frequencies when compared to the bare sample it can be ascribed to the presence of the coating itself. On the other hand, the lower frequency time constant can be attributed to corrosion processes occurring at the magnet 
(a)
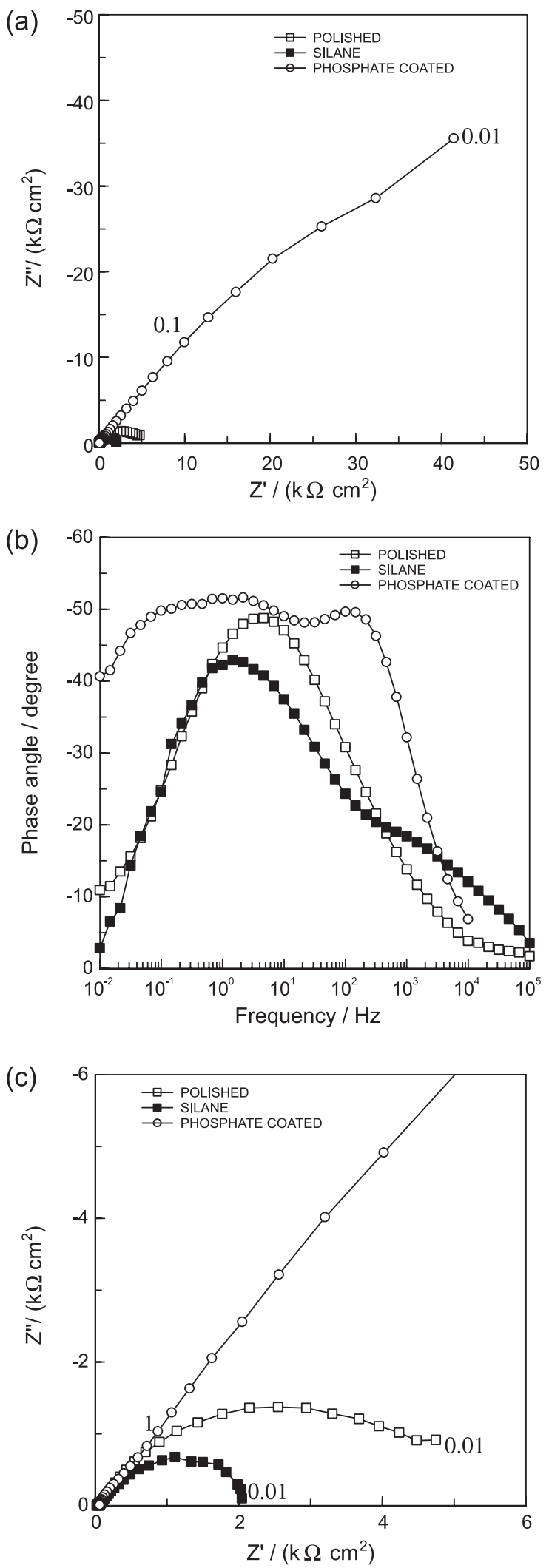

Figure 3. Nyquist (a) and Bode phase angle (b) plots of polished, phosphate and silane (BTSE) coated Nd-Fe-B magnets; (c) zoomed image of (a) showing diagrams for polished and silane coated samples. Diagrams obtained at the OCP after $1 \mathrm{~h}$ immersion in PBS solution. Typical frequencies in $\mathrm{Hz}$. surface. The analysis of the low frequency (LF) response presented in these plots indicates that the presence of the phosphate layer delays the corrosion process, as it displaces this time constant to lower frequencies. On the other hand, the LF time constant of the silane-coated sample appears on the same frequency range as the polished one indicating the occurrence of phenomena with the same kinetics, confirming, therefore, the low efficiency of this treatment for the corrosion protection of the magnet.

The analysis of the Nyquist diagram for the phosphatecoated sample shows that in the high to middle frequency range (Figure 3c) a straight line, with approximately $45^{\circ}$, is formed between the diagram and the real axis. This response is likely linked to the porous nature of the Nd-Fe-B magnet, as already discussed for the bare sample. However in this case a mixed contribution of the thin phosphate layer and of the double layer charging must be responsible for this time constant as the phase angle associated with it is clearly widened when compared with the high frequency phase angle of the bare sample.

Figure 4 presents a SEM micrograph from the surface of a silane-coated magnet. The image shows that the BTSE film is not deposited homogeneously onto the magnet surface. Regions of heavy silane deposition, identified by EDS analysis, co-exist with poorly coated ones. Particularly striking is the low affinity of the BTSE molecules for the Nd-rich regions, which present poor silane coverage even in areas characterized by heavy silane deposition. This uneven distribution of the silane on the magnet surface can explain the poor corrosion resistance exhibited by these particular samples, as galvanic cells can be formed between coated and uncoated regions. Moreover, few holes are also visible in the magnet surface, indicating that the acidic hydrolysis solution can attack the magnet surface.

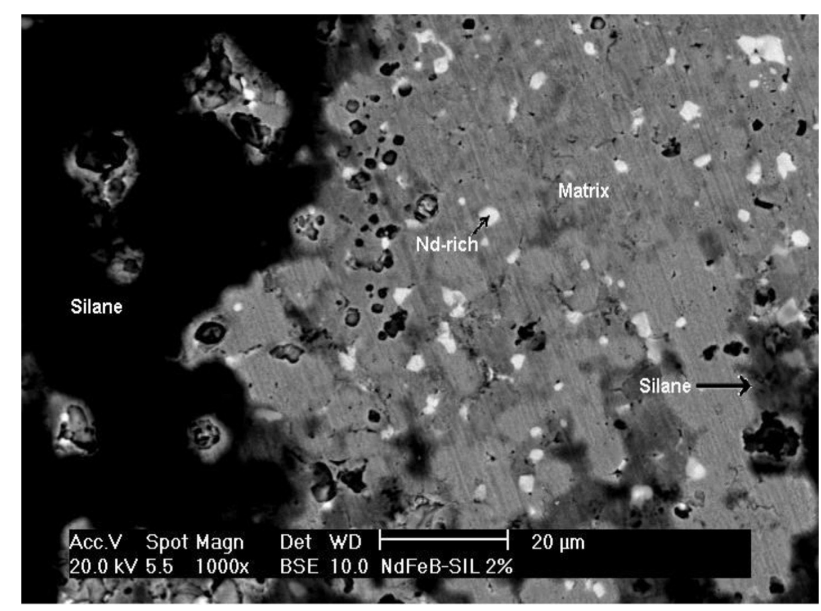

Figure 4. SEM micrograph of a silane-coated Nd-Fe-B magnet. Identification of typical Nd-rich, matrix and silane-coated regions is provided. 
In Figure 5 a SEM image of the surface of a magnet coated with the phosphate conversion layer formed during $24 \mathrm{~h}$ of immersion is presented. The image does not show the formation of a layer above the electrode surface. However naked-eye observation of the sample surface after the deposition procedure clearly revealed the existence of interference colors, indicating the presence of a thin film on the electrode surface. Moreover, a detailed EDS survey performed at different spots of the coated sample revealed the presence of phosphorus, confirming the presence of the film.

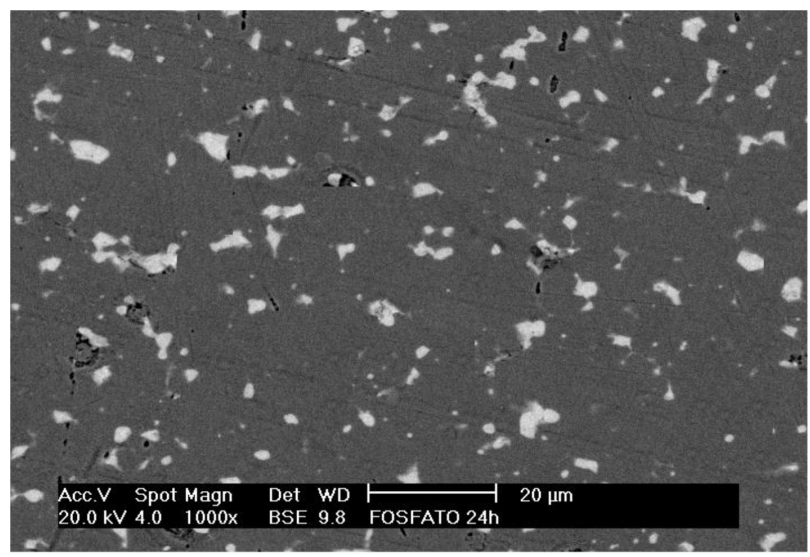

Figure 5. SEM image of the surface of a magnet coated with the phosphate conversion layer formed during $24 \mathrm{~h}$ of immersion.

The analysis of the image presented in Figure 5 reveals that the Nd-rich phase (white spots) is not corroded due to the immersion in the phosphating solution. The low corrosion resistance of the $\mathrm{Nd}-\mathrm{Fe}-\mathrm{B}$ magnets is normally ascribed to the electrochemical activity of this phase,${ }^{4}$ however during the phosphating treatment no preferential attack could be observed in this phase. Indeed SEM observation of samples coated in the phosphate solution for shorter periods revealed that the matrix was more heavily attacked than the $\mathrm{Nd}-\mathrm{Fe}-\mathrm{B}$ phase. The solubility of the $\mathrm{Nd}$ phosphate is extremely low, ${ }^{13,19}$ we propose that during the first moments of immersion of the magnet in the phosphating solution a thin insoluble film of Nd phosphate would be formed above the Nd-rich phase protecting this phase from further attack. This was supported by EDS analyses above these phases, which gave higher $\mathrm{Nd}$ contents than in the polished sample allied with an intense phosphorus peak. Increasing the treatment time would make the film spread out all over the sample surface and within the pores improving its protective properties.

Figure 6 presents backscattered SEM images of the surface of an uncoated (Figure 6a) and of a phosphatecoated (Figure $6 \mathrm{~b}$ ) magnet after $4 \mathrm{~h}$ of immersion in the
PBS solution. The images show that while the uncoated sample was extremely etched during the test only localized regions were attacked when the sample was coated with the phosphate layer. Particularly striking in Figure $6 \mathrm{~b}$ is the fact that the Nd-rich phase particles remain almost unattacked during the test, confirming the extra protection afforded to this phase by the phosphate layer.

(a)

(b)
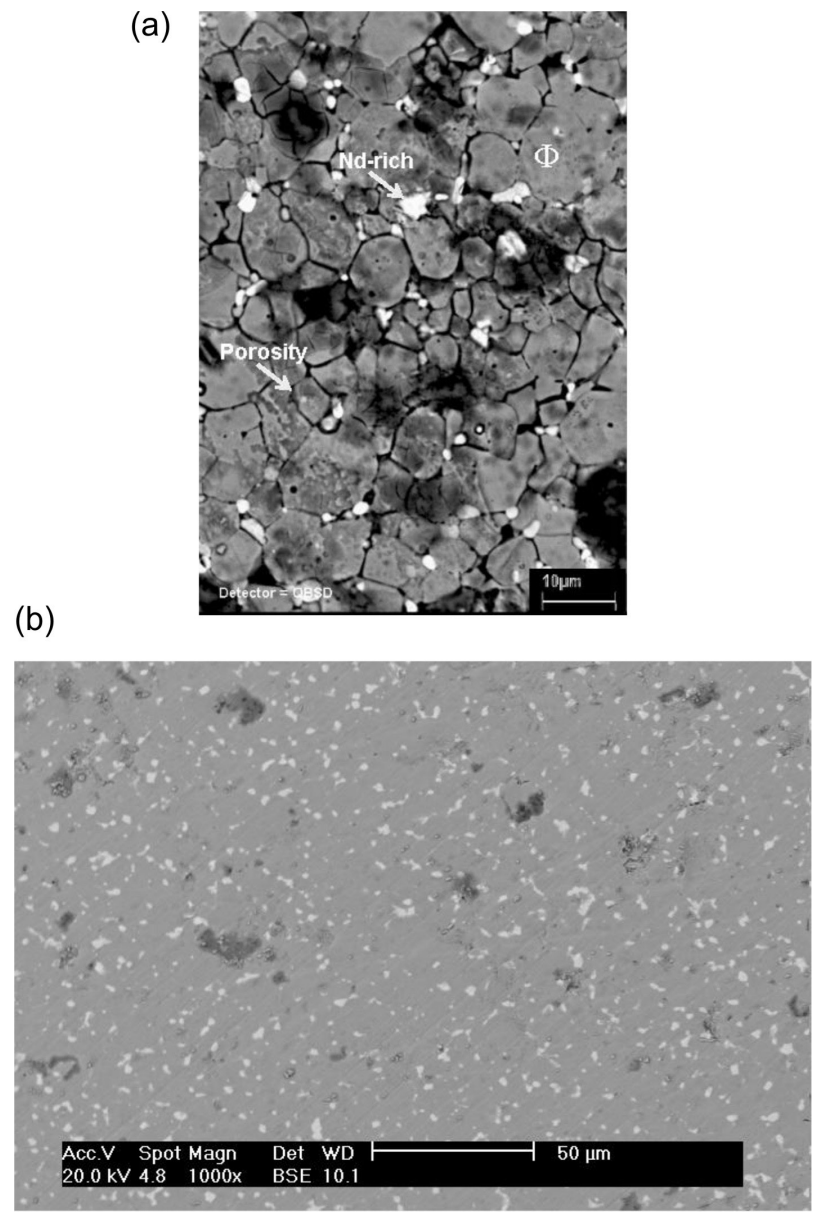

Figure 6. SEM images of an uncoated (a) and a phosphate-coated (b) $\mathrm{Nd}-\mathrm{Fe}-\mathrm{B}$ magnet after $4 \mathrm{~h}$ immersion in the PBS solution. Magnification of (a) image was $1300 \times$ and for (b) image $1000 \times$. In Figure (a) identification of typical Nd-rich, $\Phi$-phase and porosity domain is provided.

In order to better understand the protection mechanism afforded by the phosphate layer, a polished magnet sample was immersed in the phosphating bath, and its impedance behavior was followed during $24 \mathrm{~h}$ of immersion, in this case, to accelerate data acquisition, the experiments were performed at an acquisition rate of only 4 points per frequency decade. The results are presented in Figure 7 as Nyquist and Bode phase angle plots. The diagrams show increasing impedance responses for increasing immersion times, moreover two time constants are clearly distinguishable. The one in the low frequency domain, which seems to be linked to diffusion controlled process, 
is displaced to lower frequencies with immersion time, indicating increasing resistance to the corrosion process that leads to the formation of the phosphate film. On the other hand, in the high frequency region, a straight line making an angle of approximately $45^{\circ}$ is verified, pointing towards a porous electrode response; in addition the low frequency limit of this time constant is displaced to lower frequencies as the treatment time increases. This is indicative of the formation of the phosphate film on the pore walls. According to our interpretation, as the treatment time increases the pore walls are progressively coated with the phosphating layer. As the pores are more deeply coated, the corrosion process, which leads to the phosphate layer precipitation, takes place more deep within
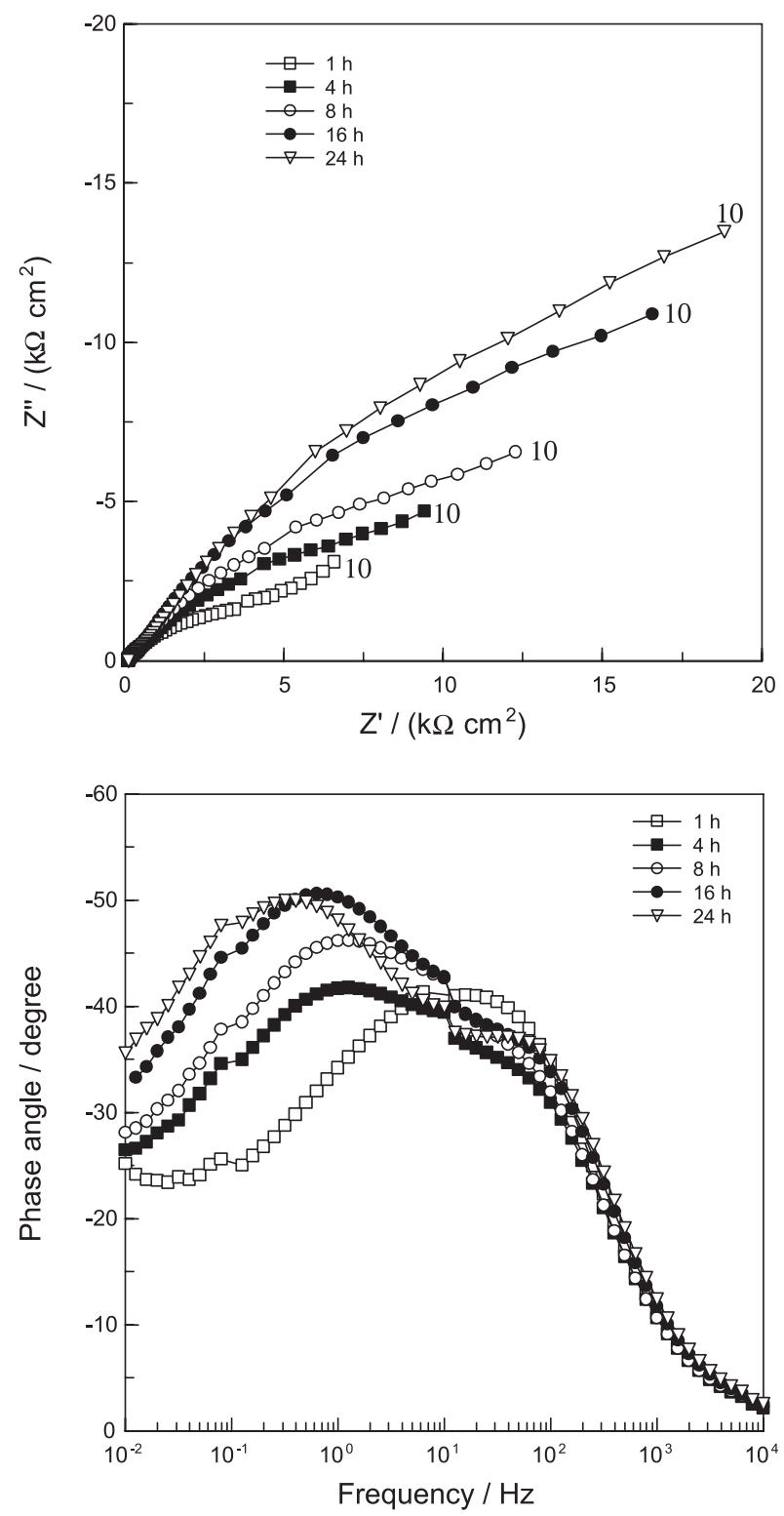

Figure 7. Evolution of the EIS response of a Nd-Fe-B magnet with immersion time in the phosphating bath. Typical frequencies in $\mathrm{mHz}$. the pores, explaining the displacement of the diffusion controlled process to lower frequencies. Differently from the uncoated sample immersed in the PBS solution an impedance response of porous electrode with semi-infinite pore length is not developed in the whole frequency range as the low frequency region of the impedance diagram, where a diffusion controlled process seems to take place, does not present a porous electrode response, which would be characterized by a $22.5^{\circ}$ angle as depicted in Figure $2 \mathrm{c}$. The impedance response also indicates that a diffusion controlled process controls the precipitation of the phosphate layer.

\section{Conclusions}

In the present work the electrochemical behavior of a powder metallurgy produced $\mathrm{Nd}-\mathrm{Fe}-\mathrm{B}$ magnet in PBS solution was investigated as well as the corrosion protection afforded by two different types of surface treatment: a phosphate and a silane (BTSE) layer.

The results of the EIS investigation have showed that, in the PBS solution, the $\mathrm{Nd}-\mathrm{Fe}-\mathrm{B}$ magnet behaves like a porous electrode with semi-infinite pore length, giving the EIS response predicted by the de Levie theory, ${ }^{16}$ which is consistent with the microstructure of a material produced by powder metallurgy.

The surface treatment of the $\mathrm{Nd}-\mathrm{Fe}-\mathrm{B}$ sintered magnet with the silane (BTSE) showed low affinity of the BTSE molecules for the Nd-rich regions, leading to poor silane coverage of this electrochemically active phase, even in the regions of heavy silane deposition. The uneven distribution of silane on the magnet surface explains the poor corrosion protection afforded by this coating, as galvanic cells can be formed between coated and uncoated regions.

The phosphating treatment produced a thin protective layer, not detectable by SEM observation but visible at naked-eye through interference colors. Unlike the silane treatment, this treatment does not attack the active $\mathrm{Nd}-\mathrm{Fe}-\mathrm{B}$ active phase. It is postulated that the phosphating solution provokes the precipitation of $\mathrm{Nd}$ phosphates mainly above the $\mathrm{Nd}$ rich phase, protecting it from further corrosion. This hypothesis was supported by SEM-EDS results which showed that after the phosphating treatment the $\mathrm{Nd}$ content on the $\mathrm{Nd}$ rich phase was increased when compared to the polished sample.

\section{Acknowledgments}

Financial support to this work by Brazilian agency CNEN is gratefully acknowledged. 


\section{References}

1. Sagawa, M.; Fujimura, S.; Togawa, N.; Yamamoto, H.; Matsuura, Y.; J. Appl. Phys. 1984, 55, 2083.

2. Campbell, P.; Permanent Magnet Materials and Their Application, Cambridge University Press: New York, 1994.

3. Harris, I. R.; Mater. Sci. Technol. 1990, 6, 962.

4. El Aziz, A. M.; Kirchener, A.; Gutfleisch, O.; Geber. A.; Shultz, L.; J. Alloys Compd. 2000, 311, 299.

5. Man, H. H.; Man, H. C.; Leunl, K.; J. Magn. Magn. Mater. 1996, 152, 47.

6. Blackwood, D. J.; Balakrisnan, B.; Huang Tan, C. K.; J. Magn. Magn. Mater. 2001, 223, 103.

7. Cheng, F. T.; Man, H. C.; Chan, W. M.; Cheng, C. W.; Chan, W. O.; J. Appl. Phys. 1999, 85, 5690.

8. Van Ooij, W. J.; Zhu, D. Q.; Corrosion 2001, 57, 413.

9. Zhu, D. Q.; Van Ooij, D. J.; Eletrochim. Acta 2004, 49, 1113.

10. Zucchi, F.; Grassi, V.; Frignani, A.; Monticelli, C. Trabanelli, G.; Surf. Coat. Technol. 2006, 200, 4136.

11. Novak, S.; Kobe, S.; Mcguiness, P.; Powder Technol. 2004, 139, 140.
12. Hu, J.-M.; Liu, X.-L.; Zhang, J.-Q.; Cao, C.-N.; Prog. Org. Coat. 2006, 55, 388.

13. Saliba-Silva, A. M.; Costa, I.; Key Eng. Mater. 2001, 189-191, 363.

14. Saliba-Silva, A. M.; De Melo, H. G.; Baker, M. A.; Brown, A. M.; Costa, I.; Mater. Sci. Forum 2003, 54, 416.

15. De Levie, R.; Electrochim. Acta 1963, 8, 751.

16. De Levie, R.; Electrochim. Acta 1964, 9, 1231.

17. De Levie, R. In Advances in Electrochemistry and Electrochemical Engineering; Vol. 6, Delahay, P., ed., New York, 1967, pp. 329-397.

18. Barcia, O. E.; D’Elia, E.; Frateur, I.; Mattos, O. R.; Pébère, N.; Tribollet, B.; Electrochim. Acta 2002, 47, 2109.

19. Takeuchi, S. M. T.; Azambuja, D. S.; Saliba-Silva, A. M.; Costa, I.; Surf. Coat. Technol. 2006, 24, 6826.

Submitted: May 5, 2010 Published online: September 23, 2010

FAPESP has sponsored the publication of this article. 